\title{
Athletic Games for The Motion of Children with Spesial Needs: a Literatur Review
}

\author{
Arif Budiman*1, Atrup ${ }^{2}$, Hendra Mashuri ${ }^{3}$ \\ Universitas Nusantara PGRI Kediri, Indonesia \\ *arifbudimanpenkep@gmail.com
}

\begin{abstract}
Children with special needs (ABK) tend to be passive, because they have physical or mental deficiencies. In addition, children with special needs have problems in the psychomotor realm as a result of limited sensomotor abilities and limitations in learning abilities. This can be handled through physical education for children with special needs, because it can develop the limitations that each child has. Physical education that can be done is through games. Games that can be done in physical education are athletic games. Athletic games can stimulate a child's ability both sensory motor skills, strength development, intellectual development, emotional aspects and socialization for children with special needs. The purpose of this review literature is to find out various kinds of aletic games for the movement of children with special needs. Literature review using the method used is through the literature search system on google scholar with the keyword athletic games against the movement of children with special needs. The literature used has full text inclusion criteria, the subject is children with special needs in special primary schools, the type of literature is the criteria for the last 6 years. Based on the results of the literature review, it was found that there were various kinds of athletic games on the movements of children with special needs. The conclusion of the review literature is that various athletic games can affect the movement of children with special needs.
\end{abstract}

Keywords : Athletic Games, Motion Of Children With Special Needs, Literature Review

Received May 28, 2020; Revised June 29, 2020; Accepted July 25, 2020 


\section{STRADA Jurnal Ilmiah Kesehatan}

DOI: $10.30994 /$ sjik.v9i2.336

ISSN: 2252-3847 (print); 2614-350X (online)

Vol.9 No.2 November 2020 Page.429-434

\section{BACKGROUND}

Children with special needs (ABK) are more likely to be passive than normal children, because they have physical or mental deficiencies that make it difficult to develop and really need special guidance. Almost all types of disability of children with special needs have problems in the psychomotor realm. Psychomotor problems as a result of limited sensomotor abilities and limitations in learning abilities. So, it can be ascertained that the role of physical education for children with special needs greatly affects which in turn will develop the limitations that each child has (Hadiyatullah, 2016).

Physical education for children with special needs can be done through games. This is because games stimulate the abilities of a child, both motor sensory abilities, strength development, intellectual development, emotional aspects and socialization. Through games, you can improve your ability to move, so your physical fitness will be better and more trained. If the physical fitness condition increases, the body will be healthier and fitter. So that later it can encourage cognitive intelligence, develop muscle strength, train balance and coordination of movements, and children with special needs will feel confident in living their daily lives, able to live independently, become productive people, so that they can be appreciated and accepted by the community (Huda, 2015). ). School games for children can be applied to athletic games.

Athletics is the oldest sport, as old as the first human in the world. This is easy to understand because humans at that time had to walk, run, jump and throw to survive. According to Purnomo (2007) athletics is the oldest sport and is the parent of all sports whose movements are the basic types and patterns of human life. The movements in athletics are movements that humans do everyday. Athletics is defined as physical activity or physical exercise, consisting of basic or natural movements such as walking, running, jumping and throwing. Because athletics is a movement that is carried out by humans every day, in life, humans must have carried out running, walking, jumping and throwing movements. Athletic sports have been known for a long time in various nations, then developed with conditions and improvements in facilities, techniques and styles. Athletics is the basis for carrying out the forms of movement found in other sports. The basic athletic movements are running, jumping and throwing.

Students with special needs have the same rights as all without special needs in obtaining education and learning at every level of education. Educational services for children with special needs need to be provided elegantly to children with special needs. Because they are also the nation's children who are the hope of parents, society and the state. In addition, they can also grow and develop into adults who have self-confidence and high self-esteem in devoting themselves to the Indonesian nation in the future (Utami, 2015). According to research conducted by Dimyati (2015) that the main difficulty in teaching physical education for deaf children is communication problems, teachers in providing instructions and providing elaboration of the material presented must use language that is already mastered by deaf students, so as not to cause misperception by students. Apart from communication problems, deaf students also tend to be more difficult to manage. Research conducted by Irawan and Pujianto (2015) resulted that the throw and run athletic game could be used to teach the movement of deaf students of SDLB Negeri Semarang in 2015. Athletic games can be applied in learning basic motion for students with special needs with hearing impairment (Dimyati, 2017). According to Aji (2015) that the athletic game model of children in learning can be used as an alternative in delivering athletic motion learning material for the Deaf SDLB running numbers. Dimyati (2017) 


\section{STRADA Jurnal Ilmiah Kesehatan}

DOI: $10.30994 /$ sjik.v9i2.336

ISSN: 2252-3847 (print); 2614-350X (online)

Vol.9 No.2 November 2020 Page.429-434

adds that the development of formula 1 games (Run, jump, throw) can be applied to learning motion for deaf students in SDLB.

Based on the background above, this journal review aims to find out various kinds of magnetic games for the movement of children with special needs.

\section{METHODS}

The inclusion criteria used were: full text (downloadable literature), human (the subjects in this study were children with special needs with hearing impairment in primary school specialties, the type of literature was the last 6 years. The method used in this literature review is By using the Google Scholar search system method through the keyword athletic games against the movement of children with special needs. Furthermore, journals that match the keywords are reviewed based on intervention models, methods, samples, and research results.

Table 1. Research characteristics

\begin{tabular}{|c|c|c|c|c|c|}
\hline No & Authors & $\begin{array}{c}\text { Model } \\
\text { intervention }\end{array}$ & Methods & Sampel & Results \\
\hline 1. & $\begin{array}{l}\text { Irawan \& } \\
\text { Pujianto, } \\
2015\end{array}$ & $\begin{array}{l}\text { Development } \\
\text { of the throw } \\
\text { and run } \\
\text { athletic game } \\
\text { model }\end{array}$ & $\begin{array}{l}\text { Development } \\
\text { research }\end{array}$ & $\begin{array}{l}\text { Students with } \\
\text { special needs } \\
\text { (Deaf) at } \\
\text { SDLB Negeri } \\
\text { Semarang in } \\
2015\end{array}$ & $\begin{array}{l}\text { Throw and run } \\
\text { athletic games can } \\
\text { be used for } \\
\text { learning motion } \\
\text { for deaf students } \\
\text { at SDLB Negeri } \\
\text { Semarang }\end{array}$ \\
\hline 2. & Aji, 2015 & $\begin{array}{l}\text { Model of } \\
\text { children's } \\
\text { athletic games } \\
\text { in learning the } \\
\text { basic motion } \\
\text { of running }\end{array}$ & $\begin{array}{l}\text { Development } \\
\text { research }\end{array}$ & $\begin{array}{l}20 \text { students } \\
\text { with special } \\
\text { needs (deaf) } \\
\text { SDLB Negeri } \\
\text { Semarang in } \\
2015\end{array}$ & $\begin{array}{l}\text { The resulting } \\
\text { product can be } \\
\text { used as an } \\
\text { alternative } \\
\text { delivery of } \\
\text { learning material } \\
\text { for athletic } \\
\text { movement } \\
\text { numbers for } \\
\text { special school } \\
\text { students. }\end{array}$ \\
\hline 3. & $\begin{array}{l}\text { Dimyati, } \\
2017\end{array}$ & $\begin{array}{l}\text { Formula } 1 \\
\text { game } \\
\text { development } \\
\text { (Run, jump, } \\
\text { throw) }\end{array}$ & $\begin{array}{l}\text { Development } \\
\text { research }\end{array}$ & $\begin{array}{l}\text { SDLB Deaf } \\
\text { Students } \\
\text { (Small group } \\
\text { trial of } 20 \\
\text { students and } \\
\text { large group } \\
\text { trial of } 65 \\
\text { students) }\end{array}$ & $\begin{array}{l}\text { The product can be } \\
\text { used as an } \\
\text { alternative for the } \\
\text { delivery of material } \\
\text { in learning the basic } \\
\text { movements of } \\
\text { running to students } \\
\text { with special needs } \\
\text { in primary schools. }\end{array}$ \\
\hline
\end{tabular}

\section{RESULT}

Based on a review of 3 literatures, it was concluded that the throw and run athletic game could be used for deaf students of SDLB Negeri Semarang (Irawan \& Pujianto, 2015). The resulting product can be used as an alternative delivery of athletic learning 


\section{STRADA Jurnal Ilmiah Kesehatan}

DOI: $10.30994 /$ sjik.v9i2.336

ISSN: 2252-3847 (print); 2614-350X (online)

Vol.9 No.2 November 2020 Page.429-434

materials for special school student running numbers with a sample of 20 students with special needs (deaf) SDLB Negeri Semarang in 2015 (Aji, 2015). Research by Dimyati (2017) states that formula 1 products can be used as an alternative in delivering basic motion learning material to deaf students of SDLB. The results obtained from the literature review found that there are various kinds of athletic games on the movements of children with special needs.

\section{DISCUSSION}

The results of the literature review show that the throw and run athletic game can be used for deaf students of SDLB Negeri Semarang (Irawan \& Pujianto, 2015). The resulting product can be used as an alternative delivery of athletic learning material for special school student running numbers (Aji, 2015). Formula 1 game products can be used as an alternative in delivering basic motion learning material to special school students (Dimyati, 2017). The results obtained from some of the review literature found that there were various kinds of athletic games on the movements of children with special needs.

In this review article, children with hearing impairments. Deaf deafness has limitations in hearing, so that in pesjasorkes learning movement problems in communication. Children with special needs (ABK) are more likely to be passive than normal children, because they have physical or mental deficiencies that make it difficult to develop and really need special guidance. Special coaching through games is the right alternative for the movements of children with special needs. Play is useful in 1) the development of the physical aspect; 2) development of social aspects; 3) fine motor and gross motor development; 4) development of emotional and personality sapek; 5) development of aspects of cognition; 6) change the sensing sharpness; 7) developing sports and dancing skills; 8) media therapy; 9) media intervention. The benefits of the game when viewed from a different angle are 1) The benefits of playing from a health point of view, namely the movement of the body that is generated in the game has a very good effect on the organs in the body so that it can encourage growth; 2) The benefits of playing from an educational point of view, namely, when the child plays the game, he is happy, so that deliberately, the play that is done can be easily understood by the child; 3) The benefits of the game when viewed from the perspective of personal development, namely the various activities in school sports, many mental and personality functions that can be developed, for example mental balance, speed, thought processes, concentration skills, and leadership skills; 4) Games performed by children bring various benefits that can support children's development. In addition, play activities can meet the needs and impulses in children that cannot be satisfied in real life. When children have the opportunity to channel feelings of tension, pressure, and channel the impulses that come from within themselves, the child will feel relieved and relaxed. As humans who are still at a young age, children really need play activities, while according to Gunawan (2009) the reason children need play is 1) children and living things in general have the urge or desire to move. What is meant by moving here is doing planned movement activities that the body needs, especially moving from one place to another; 2) Children need the opportunity to play to train themselves, to place themselves in society, as part of their local community. Furthermore, it is preparing ourselves to live as a human being in society; 3) By giving the opportunity to play, it can give instinct to get along with other people; 4) Playing also for children can be used as a 


\section{STRADA Jurnal Ilmiah Kesehatan}

DOI: $10.30994 /$ siik.v9i2.336

ISSN: 2252-3847 (print); 2614-350X (online)

Vol.9 No.2 November 2020 Page.429-434

solution to find out their own abilities compared to other people's abilities, or their own abilities, now and in the past; 5) Children tend to have certain fantasies. By playing intermediaries, he can channel his fantasies, by becoming or imitating certain characters, for example superhero characters and others; 6) Through play, children can measure themselves, either by competing their skills, courage or fortunes with other people.

According to Irianto (2005), it is explained that the characteristics of games that are beneficial to children's development are (1) Move, which means moving, meaning that there must be movements that are carried out continuously and rhythmically. This movement can increase cardiovascular endurance and improve body composition. (2) lift, which means that in the game there must be an element of motion against the load. This movement will train muscle strength and endurance, as well as (3) Stretching, meaning that in this game, it must contain elements of motion to stretch joints including stretching muscles. In addition, this movement will train muscle joint flexibility (Sumarsono, 2017).

There are various kinds of athletic games for the movements of children with special needs. This is because games are the right alternative to overcome the limitations of children with special needs because games have great benefits, especially for children with special needs.

\section{CONCLUSION}

The conclusion obtained from the literature review is that there are various athletic games on the movements of children with special needs with hearing impairment. These games include throw and run athletic games, children's athletic games in learning the basic motion of running, and formula 1 games (Run, jump, throw). Through various games, it can be used to improve the movement of children with special needs.

\section{REFERENCES}

Aji, K.B. 2015. Pengembangan Model Permainan Atletik Anaka dalam Pembelajaran Gerak Dasar Lari bagi Siswa Berkebutuhan Khusus (Tunarungu) di SDLBNegeri

Semarang Tahun 2015. Skrispi: Pendidikan Jasmani Kesehatan dan Rekreasi,

Fakultas Ilmu Keolahragaan Universitas Negeri Semarang.

Dimyati, A. 2017. Pengembangan Model Permainan Atletik Anak dalam Pembelajaran Gerak Dasar Lari Bagi Siswa Berkebutuhan Khusus (Tunarungu) di SLB Negeri Kabupaten Karawang. Journal Sport Area, 19-26.

Gunawan, W. 2009. 50 full ceative games. Yogyakarta: Aimatea.

Hidayatullah, M. 2016. Pengembangan Model Permainan Larompar dalam Pembelajaran Pendidikan Jasmani pada Siswa AMPLB-B (Tunarungu) di Kabupaten Semarang Tahun 2016. Skrispi: Pendidikan Jasmani Kesehatan dan Rekreasi, Fakultas Ilmu Keolahragaan Universitas Negeri Semarang.

Huda, S. 2015. Manfaat Permainan Terapeutik Balap Karung Terhadap Peningkatan Kemampuan Lari Sprint dan Lompat Jauh Anak Tunagrahita Ringan Usia 6-10 Tahun. Jurnal Kesehatan Olahraga, 3(1): 238-243.

Irawan, I.S. \& Pujianto, A. 2015. Pengembangan Model Pembelajaran Gerak Dasar Lari Melalui Permainan Throw and Run Pada Siswa Berkebutuhan Khusus (Tunarungu) di SDLB Negeri Semarang Tahun 2015. Journal of Physical Education, Sport, Health and Recreations, 4(7): 1920-1925. 


\section{STRADA Jurnal Ilmiah Kesehatan}

DOI: $10.30994 /$ sjik.v9i2.336

ISSN: 2252-3847 (print); 2614-350X (online)

Vol.9 No.2 November 2020 Page.429-434

Irianto, D. P. 2005. Pedoman praktis berolahraga untuk kebugaran dan kesehatan. Yogyakarta: Andi Offset.

Purnomo, E. 2007. Pedoman Mengajar Dasar Gerak Atletik. Yogyakarta: UNY Press.

Sumarsono, A. 2017. Implementasi Model Pembelajaran Atletik Melalui Permainan Berbasis Alam. Jurnal Magistra, 4(2): 070-083.

Utami, G.G. 2015. Pengembangan Model Kids Atletik dengan Permainan Fun Post pada Siswa SDLB C Dharma Bhakti Kab.Semarang Tahun 2015. Skrispi: Pendidikan Jasmani Kesehatan dan Rekreasi, Fakultas Ilmu Keolahragaan Universitas Negeri Semarang. 